\title{
Is interleukin-8 a true predictor of pediatric acute respiratory distress syndrome outcomes? Beware of potential confounders
}

\author{
Sébastien Redant ${ }^{1}$, François Angoulvant ${ }^{2}$, Oceane Barbance ${ }^{1}$, David De Bels ${ }^{1}$, Andrea Gallerani ${ }^{1}$, Rachid Attou', \\ Kianoush Kashani ${ }^{3}$ and Patrick M. Honore ${ }^{1 *}$
}

This comment refers to the article available at https://doi.org/10.1186/s13054-019-2342-8

We enthusiastically read the study by Flori et al. related to the potential association of interleukin-8 (IL8) with the outcomes of pediatric acute respiratory distress syndrome (PARDS) following respiratory tract infection. In this study, IL-8 found to be associated with mortality, duration of ventilation, pediatric intensive care unit (PICU) length of stay, and the degree of pulmonary morbidity, measured by oxygenation defect. Meanwhile, IL8 was not found to be associated with the occurrence of PARDS, per se [1]. Samransamruajkit et al. previously in a single-center study reported an association between mortality in PARDS and IL-8 levels $(1288.7 \pm 638$ among non-survivors vs. $257 \pm$ $366 \mathrm{pg} / \mathrm{ml}$ in survivors, $P=.001$ ) [2]. IL-8 is secreted by the lung endothelial cells in response to injury induced by infections or toxins. IL-8 concentration in bronchoalveolar lavage was found to be 5 to 10 times higher in the day of intubation when compared with control subjects. This indicates a substantial inflammation which leads to an increase of intra-alveolar neutrophils [3]. Hall et al. showed a significant association between IL-8 levels and respiratory infection with the H1N1 virus. IL8 levels in these patients were significantly higher when compared with other influenza subtypes (median of 55(13-201) vs. $0(0-13) \mathrm{pg} / \mathrm{mL} ; P<.0001)$ [4]. A similar observation was made for Staphylococcus aureus in comparison with other microorganisms $\quad(164(52-4424) \quad$ vs. $6.1(0-22) \quad \mathrm{pg} / \mathrm{ml}$; $P=.0002)$ [4]. On the other hand, the PARDS-associated mortality rate is different based on the type of infection [5]. Hence, it would be reasonable to be cautious in the extrapolation of the knowledge related to PARDSassociated mortality when it is due to RSV versus PARDSassociated death in other infections [5]. Since the type of microorganism or virus influences the IL-8 level and PARDS outcome, we suggest the relationship of the IL-8 concentration and PARDS outcomes be stratified based on the type of causing microorganism or virus.

\section{Authors' response}

Heidi Flori and Mary K. Dahmer

We appreciate the insightful commentary by Dr. Redant and colleagues on our publication demonstrating that IL-8 is associated with poor outcome in children with severe acute respiratory failure, many of which had pediatric acute respiratory distress syndrome (PARDS) [1]. Indeed, it is important for research to generate the "next questions" to investigate. This is particularly true

\footnotetext{
* Correspondence: Patrick.Honore@CHU-Brugmann.be

${ }^{1}$ ICU Department, Centre Hospitalier Universitaire Brugmann-Brugmann University Hospital, Place Van Gehuchtenplein, 4, 1020 Brussels, Belgium Full list of author information is available at the end of the article
}

for understanding which biological markers may be impacted by individual disease processes, types of infection, host response characteristics, etc. Such understanding is the impetus behind the "precision medicine" movement.

Dr. Redant et al. suggest that analysis of the relationship between IL-8 and outcomes be stratified by type of microorganism causing infection. However, as an ancillary study to a sedation management trial, we do not have detailed infectious agent data. As shown in the supplement, median IL-8 levels varied by primary diagnosis; sepsis patients had a higher median IL-8 than those with 
pneumonia or bronchiolitis. Although not reported in the paper, IL-8 is independently associated with the duration of mechanical ventilation $(P<0.0005$, all days) after adjusting for age, PRISM-III, and primary diagnoses (pneumonia [37\%], bronchiolitis [20\%], sepsis [19\%], asthma [10\%], aspiration pneumonia [6\%], and other [8\%]). Since the group with sepsis likely has a higher proportion of bacterial infections, and those with bronchiolitis likely have a high proportion with viral infections, one might speculate that IL-8 is associated with poor outcome independent of a bacterial or viral etiology. However, analysis of microorganism-based subgroups would be a much "cleaner" way to examine that question, yet such a strategy is hampered by the size of pediatric cohorts. Although the BALI study is one of the largest multi-center cohorts of pediatric acute respiratory failure and PARDS patients, our subgroup analyses still suffered from low numbers, especially when adjusting for important covariates. We anticipate this is also true for most other PARDS cohorts.

In summary, we agree there is value in stratifying analyses of IL-8 and outcomes by an infectious agent, which would demonstrate whether IL-8 is associated with outcome irrespective of underlying etiology, or, alternatively, varies by infectious agent. The use of a common set of data elements in PARDS-related studies may allow this question to be addressed in the future by combining datasets from multiple studies. Nonetheless, IL-8 remains an intriguing biomarker of inflammation in critical illness where it may be useful for stratification into endotypes [6] allowing predictive and prognostic enrichment for trials, and/or as a marker of disease trajectory with regard to response to therapy [7].

\section{Abbreviations}

IL8: Interleukin-8; PARDS: Pediatric acute respiratory distress syndrome;

PICU: Pediatric intensive care unit; RSV: Respiratory syncytial virus

\section{Acknowledgements}

None.

\section{Authors' contributions}

SR, KK, and PMH conceived the paper. All authors participated in drafting and reviewing. All authors read and approved the final version of the manuscript.

\section{Funding}

None.

Availability of data and materials

Not applicable.

Ethics approval and consent to participate

Not applicable.

Consent for publication

Not applicable.

Competing interests

The authors declare that they have no competing interests.

\section{Author details}

IICU Department, Centre Hospitalier Universitaire Brugmann-Brugmann University Hospital, Place Van Gehuchtenplein, 4, 1020 Brussels, Belgium. ${ }^{2}$ Service d'accueil des urgences pédiatriques, Necker- Enfants Malades University Hospital, Assistance Publique-Hôpitaux de Paris, Paris, France. ${ }^{3}$ Division of Nephrology and Hypertension, Division of Pulmonary and Critical Care Medicine, Mayo Clinic, Rochester, USA.

Received: 9 May 2019 Accepted: 6 June 2019

Published online: 27 June 2019

\section{References}

1. Flori H, Sapru A, Quasney MW, Gildengorin G, Curley MAQ, Matthay MA, et al. A prospective investigation of interleukin-8levels in pediatric acute respiratory failure and acute respiratory distress syndrome. Crit Care. 2019; 23:128 https://doi.org/10.1186/s13054-019-2342-8.

2. Samransamruajkit $R$, Jiraratanawong $K$, Siritantiwat S, Chottanapan S, Deelodejanawong J, Sritippayawan $\mathrm{S}$, et al. Potent inflammatory cytokine response following lung volume recruitment maneuvers with HFOV in pediatric acute respiratory distress syndrome. Asian Pac J Allergy Immunol. 2012;30(3):197-203.

3. Todd DA, Marsh MJ, George A, Henderson NG, Barr H, Sebastian S, et al. Surfactant phospholipids, surfactant proteins, and inflammatory markers during acute lung injury in children. Pediatr Crit Care Med. 2010;11(1):82-91. https://doi.org/10.1097/PCC.0b013e3181ae5a4c.

4. Hall MW, Geyer SM, Guo CY, Panoskaltsis-Mortari A, Jouvet P, Ferdinands J, et al. Innate immune function and mortality in critically ill children with influenza: a multicenter study. Crit Care Med. 2013;41(1):224-36. https://doi. org/10.1097/CCM.0b013e318267633c.

5. Khemani RG, Smith LS, Zimmerman JJ, Erickson S, Pediatric Acute Lung Injury Consensus Conference Group. Pediatric acute respiratory distress syndrome: definition, incidence, and epidemiology: proceedings from the Pediatric Acute Lung Injury Consensus Conference. Pediatr Crit Care Med. 2015;16(5 Suppl 1):S23-40. https://doi.org/10.1097/PCC.0000000000000432.

6. Calfee $\mathrm{CS}$, Delucchi $\mathrm{KL}$, Sinha $\mathrm{P}$, et al. Acute respiratory distress syndrome subphenotypes and differential response to simvastatin: secondary analysis of a randomised controlled trial. Lancet Respir Med. 2018;6(9):691-698. https://doi.org/10.1016/S2213-2600(18)30177-2.

7. Zinter MS, Orwoll BE, Spicer AC, et al. Incorporating inflammation into mortality risk in pediatric acute respiratory distress syndrome. Crit Care Med. 2017:45:858-66.

\section{Publisher's Note}

Springer Nature remains neutral with regard to jurisdictional claims in published maps and institutional affiliations. 